\title{
Study on the Status of International Students' Satisfaction with the Quality of Higher Education Service
}

\author{
CHEN Qiting \\ Nanjing University of Aeronautics and Astronautics \\ College of Economic and Management \\ Nanjing, China \\ chen_qiting@163.com
}

\author{
MIAO Qianqian \\ Nanjing University of Aeronautics and Astronautics \\ College of Economic and Management \\ Nanjing, China \\ 270401289@qq.com
}

\begin{abstract}
- the research designed a survey and took a college in Nanjing as the cases to evaluate the international student satisfaction of higher education service quality. Survey results show that students are not satisfied with the overall service quality of higher education. Study finds 6 factors influencing student satisfaction in descending order are College reputation, Campus environment, Academic quality, teaching facilities, Logistics service and teacher troop. Eight variables have significant gender differences. Professional has no significant impact on overall satisfaction while grade have significant impact on overall satisfaction.
\end{abstract}

Keywords—service quality, student satisfaction, factor analysis, gender difference

\section{INTRODUCTION}

With the development of the global economic, China's higher education has been increasingly competitive. Various studies have focused on the role of quality in higher education in order to become competitive in the global arena (Aldridge \&Rowley,1998;Athiyaman,1997;Moogan,Baron,\&Bainbridge, 2001; Oldfield\&Baron,2000) $)^{[1][2][3][4]}$. Continuous improvement of existing standards and increased students' satisfaction has been key issues in service quality at higher educational institutions in China. Both levels of satisfaction and perception of quality will likely determine students' retention at higher education institutions. Enhancing educational value is to expend effort on continuous improvement, focus on stakeholders' interests and to increase students' satisfaction which is often used to assess quality of education. The purpose of this study is to investigate the predication of international students' satisfaction with their university, including the role that gender differences play. The study examines some of the criteria used by students (including service quality, the trust in the management of the institution and their perception of the management's readiness to change) when choosing or evaluating a tertiary institution in China.

In many other countries, there are many researches about the students' satisfaction. The American Heritage Dictionary $(1982)^{[5]}$ defines satisfaction as the "the fulfillment or gratification of a desire, need, or appetite", Kotler and Clarke $(1987)^{[6]}$ defines satisfaction as the desirous outcome of a task or job that pleases one's esteem., Schreiner \& Juillerat,(1994) ${ }^{[7]}$ defined student satisfaction as "when expectations are met or exceeded by the student's perception of the campus reality. Sweeney and Ingram(2001) ${ }^{[8]}$ define student satisfaction as "The perception of enjoyment and accomplishment in the learning environment".

"Evaluation of student satisfaction of internal performance of universities helps higher education institutions to identify what makes them distinctive and discover critical areas that have less satisfying and need to be improved to meet student expectations. Addressing the demands and needs of students is critical for higher educational institutions.

In China, some researchers such as Fang Baojun (2010) ${ }^{[9]}$ defined the quality of teaching is the sum of teaching standards and its practice effect .Student s satisfaction is the important reference standard to access the teaching quality. Yang Lanfang(2011) ${ }^{[10]}$ finds principal factors influencing student satisfaction in descending order are professional curriculum, campus culture, faculty, practical innovation, logistics service, supplementary facilities.

The purpose of this study is the determination of factors affecting international student satisfaction of Chinese university. To complete this purpose, the research question regarding the factor structure for the SSI will be answered: Which factors have more affective impact on student satisfaction in University?

\section{METHODOLOGY}

\section{A. The sample framework}

The Student Satisfaction was based on survey data gathered (summer 2014) from students attending one college. All respondents in this survey completed the same questionnaire. The questionnaires were distributed to randomly selected students in pre-determined classes. A total sample of 1000 students was randomly selected in class context at the university in China, and 883 valid questionnaires were recycled. The sample comprised of 19.1 percent female students. 


\section{Ariants PRESS}

\section{B. Measuring instrument and reliability}

Information about specific aspects of service quality in HE. The list of items developed to measure service quality in $\mathrm{HE}$ was based on an extensive literature research and the findings of preliminary focus groups consisting of students and lecturers. Adopting an approach similar to the SERVQUAL methodology and the importance-performance technique (Martilla \& James, 1977) $)^{[11]}$, students were asked about the importance (I) (rated on a 5-point Likert-type scale from 'very important' to 'not important at all'), as well as the perceived experiences (P) (rated on a 5-point Likert-type scale from 'excellent' to 'not good at all') for each of the 52 items on the scale. The resulting instrument, a structured questionnaire, included several variables related to service quality at higher educational institutions - the service quality scale (De Jager \& Gbadamosi, 2009) ${ }^{[12]}$. In this sample, the 6 scales performed very well in terms of reliability, with obtained Cronbach's alpha ranging from .752 to .935 (details are provided in table3).

\section{DATE ANALYSIS AND FINDINGS}

Overall, respondents were 19.1 percent female, 12 percent were in their first year, 43.7 percent were in their second year,
Service quality in HE: In this study the 6 factors from the scale by De Jager and Gbadamosi (2009) were used to obtain 29.5 percent were in their third year, 20 percent were within the 18-19 years. Aeronautical Engineering were 166(19.9\%), Mechanical Engineering were 140(16.8\%), Software Engineering and Technology were 298(35.8\%) and International Business were 229(27.5\%).

\section{A. Factor analysis of the students satisfaction}

Factor analysis was used as a date reduction tool and as a technique to establish some construct validity for the measure of service quality in higher education. Before the factor analysis, we should have a Bartlett Test of sphericity, KMO were 0.931 , Sig were 0.000 . The principal components analysis method was used for initial factor extraction and Varimax rotation was applied. Seven items were redundant and thus eliminated from further analysis. Six factors were identified as key dimensions of service quality in higher education. These factors were named as indicated in Table 1. Items selected with factor loading greater than 0.5 for each factor. Factors were extracted with eigenvalue greater than 2 . Total variation was 65.841 and Factor 1 account for $19.639 \%$ of total variance. Stevens(1986)Lawley \& Maxwell (1971)noted that it is acceptable if the total variance higher than $60 \%$.

TABLE I. FACTOR ANALYSIS OF THE HIGHER EDUCATION SCALE

\begin{tabular}{|c|c|c|c|c|c|c|}
\hline \multirow[b]{2}{*}{ item } & \multicolumn{6}{|c|}{ Factors---perception of service quality } \\
\hline & 1 & 2 & 3 & 4 & 5 & 6 \\
\hline \multicolumn{7}{|l|}{ Factor1: College reputation } \\
\hline College reputation compared with other college in same level & .725 & & & & & \\
\hline professional knowledge & .679 & & & & & \\
\hline ability and quality & .674 & & & & & \\
\hline happiness during learning & .669 & & & & & \\
\hline choose again or not & .662 & & & & & \\
\hline College reputation compared with other engineering college & .661 & & & & & \\
\hline future employment & .654 & & & & & \\
\hline features of university's education & .651 & & & & & \\
\hline overall education quality & .605 & & & & & \\
\hline overall image of college & .595 & & & & & \\
\hline teachers & .523 & & & & & \\
\hline \multicolumn{7}{|l|}{ Factor2: Campus environment } \\
\hline employment information & & .728 & & & & \\
\hline Psychological counseling & & .697 & & & & \\
\hline academic exchanges/academic activities & & .683 & & & & \\
\hline Complain system & & .671 & & & & \\
\hline Patency of expressing opinions & & .620 & & & & \\
\hline Timeliness of getting help & & .585 & & & & \\
\hline Communication between counselors and students & & .512 & & & & \\
\hline \multicolumn{7}{|l|}{ Factor3: Academic quality } \\
\hline Atmosphere for learning and overall mood of campus & & & .792 & & & \\
\hline Safety of campus environment & & & .723 & & & \\
\hline Academic atmosphere & & & .683 & & & \\
\hline Elegance of campus environment & & & .676 & & & \\
\hline \multicolumn{7}{|l|}{ Factor4: Teaching facilities } \\
\hline Quality and price of meals & & & & .604 & & \\
\hline The adequacy of classrooms & & & & .554 & & \\
\hline Completeness of teaching equipment & & & & .536 & & \\
\hline Rationality of courses arrangement & & & & .536 & & \\
\hline \multicolumn{7}{|l|}{ Factor5: Logistics service } \\
\hline Completeness and convenience of dormitory facilities & & & & & .745 & \\
\hline Service attitude of dormitory management and logistics staff? & & & & & .692 & \\
\hline Completeness and Implementation of Regulation & & & & & .557 & \\
\hline \multicolumn{7}{|l|}{ Factor6: teacher troop } \\
\hline Language and expression skills of teachers & & & & & & .555 \\
\hline Diversity of teaching methods & & & & & & .550 \\
\hline education service according to students' individualized development & & & & & & .500 \\
\hline
\end{tabular}

Notes: Rotation converged in 13 iterations; extraction method: principal component analysis; rotation method: Varimax with Kaiser Normalization; factor

loadings below 0.5 are suppressed for the purpose of analysis. 
TABLE II. FACTORS' EIGENVALUE AND THE VARIANCE CONTRIBUTION RATE

\begin{tabular}{|c|c|c|c|c|}
\hline Factor & eigenvalue & $\begin{array}{c}\text { Amount of variance } \\
\text { explained } \\
(\mathbf{\%})\end{array}$ & $\begin{array}{c}\text { The cumulative variance } \\
\text { explained (\%) }\end{array}$ & $\begin{array}{c}\text { The variance } \\
\text { contribution rate (\%) }\end{array}$ \\
\hline College reputation & 7.659 & 19.639 & 19.639 & 29.83 \\
\hline Campus environment & 5.274 & 13.522 & 33.161 & 20.54 \\
\hline Academic quality & 3.985 & 10.218 & 43.379 & 15.52 \\
\hline Teaching facilities & 3.279 & 8.407 & 51.786 & 12.77 \\
\hline Logistics service & 3.183 & 8.162 & 59.948 & 8.39 \\
\hline teacher troop & 2.298 & 5.893 & 65.841 & 8.95 \\
\hline
\end{tabular}

\section{B. The reliability test}

Cronbach's alpha is used as an estimate of the reliability of a psychometric test. The alpha of College reputation is about 0.94, Campus environment is 0.91 , Academic quality is 0.82 ,
Teaching facilities is 0.75 , Logistics service is 0.78 , and teacher troop is 0.82 . It is interesting to note that the alpha of all the six factors is above 0.7 which indicated that the test is an acceptable test.

TABLE III. MEAN, VARIANCE AND CRONBACH'S ALPHA OF STUDY VARIABLES

\begin{tabular}{|c|c|c|c|c|c|}
\hline $\mathrm{S} / \mathrm{N}$ & Study variables & No. of items & Mean & variance & Alpha \\
\hline 1 & College reputation & 11 & 3.395 & 1.055 & 0.935 \\
\hline 2 & Campus environment & 7 & 3.039 & 1.182 & 0.907 \\
\hline 3 & Academic quality & 4 & 3.589 & 1.089 & 0.817 \\
\hline 4 & Teaching facilities & 4 & 3.484 & 0.961 & 0.752 \\
\hline 5 & Logistics service & 3 & 2.772 & 0.291 & 0.770 \\
6 & teacher troop & 3 & 3.197 & 0.966 & 0.815 \\
7 & overall satisfaction & 1 & 2.81 & 1.521 & - \\
\hline
\end{tabular}

Note Items * (1-6) are the named factors for service quality scale in higher education

\section{C. tudents basic characteristics impact on overall satisfaction}

\section{1) Gender differences in students' satisfaction}

The findings relating to gender differences among students across the university are presented in this section. Independent samples t-tests were conducted to examine gender differences across all study variables - Table4. Significant gender differences were found with the following variables: dormitory facilities, sports and entertainment facilities, courses arrangement, courses arrangement, administrative staff, College reputation, recommend the school to relatives, Overall expectation. Satisfaction of your college compared with your former expectation. The sports and entertainment facilities and sports and entertainment facilities and courses arrangement and administrative staff of the university are significantly more important for males than females. Male students more than the females significantly recommend the school to relatives, the female students were, however, significantly more expected overall with their university than the males.

TABLE IV. INdEPENDENT SAMPLES TEST (GENDER DIFFERENCES)

\begin{tabular}{|c|c|c|c|c|c|c|c|c|c|}
\hline \multirow[t]{2}{*}{$\begin{array}{c}\text { Study } \\
\text { variables }\end{array}$} & \multicolumn{2}{|c|}{ Male } & \multirow{2}{*}{$\begin{array}{c}\text { Female } \\
\text { Mean }\end{array}$} & \multirow[b]{2}{*}{ SD } & \multicolumn{2}{|c|}{$\begin{array}{l}\text { Levene's Test for } \\
\text { Equality of } \\
\text { variance }\end{array}$} & \multicolumn{3}{|c|}{$\mathrm{t}$-Test for equality of means } \\
\hline & Mean & SD & & & $\mathrm{F}$ & Sig & $\mathrm{t}$ & df & Sig(2-tailed) \\
\hline Q7 & 3.64 & .988 & 2.97 & 1.218 & .865 & .353 & 3.414 & 831 & .001 \\
\hline Q12 & 3.39 & .925 & 2.76 & .987 & .005 & .943 & 3.559 & 831 & .000 \\
\hline Q40 & 3.34 & 1.217 & 2.76 & 1.519 & 6.266 & .013 & 2.375 & 831 & .019 \\
\hline Q50 & 3.72 & .953 & 4.32 & .589 & 9.671 & .002 & -3.546 & 831 & .000 \\
\hline Q56 & 3.20 & 1.065 & 2.74 & 1.238 & 3.315 & .070 & 2.227 & 831 & .027 \\
\hline
\end{tabular}

2) Professional differences in students' satisfaction

Nonparametric test were conducted to examine the influence of different professional on overall satisfaction, in table 5,we can see the professional $\chi 2$ equal to 6.838 , and Concomitant probability equal to 0.077 which is greater than 0.05 , so Professional have no significant impact on overall satisfaction. 
TABLE V. PROFESSIONAL AND GRADE DIFFERENCES IN STUDENTS' SATISFACTION

\begin{tabular}{|c|c|c|c|}
\hline Grouping variable & $\chi^{2}$ & Df & progressive significance \\
\hline professional & 6.838 & 3 & .077 \\
\hline Grade & 56.723 & 3 & .000 \\
\hline
\end{tabular}

\section{3) Grade differences in students' satisfaction}

Nonparametric test were also conducted to examine the influence of different grade on overall satisfaction., we can see the grade $\chi 2$ equal to 56.723, and Concomitant probability equal to 0.000 which is less than 0.05 , so grade have significant impact on overall satisfaction.

\section{CONCLUSION}

In this paper, we have attempted to identify the major predictors of students' satisfaction with their university and the role that perception of service quality, gender differences plays in these. Firstly, Perception of service quality was assessed by 6 factors of which is College reputation, Campus environment, Academic quality, Teaching facilities, Logistics service and teacher troop. Secondly, Significant gender differences were found with the following variables: dormitory facilities; sports and entertainment facilities courses arrangement courses arrangement administrative staff College reputation recommend the school to relatives Overall expectation Satisfaction of your college compared with your former expectation. Finally, Professional has no significant impact on overall satisfaction while grade have.

According to the conclusion, we could make some suggestions. Firstly, we could adjust the schedule about the content of the course and the professional, adapting to the social development and meeting the demand of students' employment. The variance contribution of professional course is about $30 \%$, and it is the largest in all the factors'. The results fully reflect that it can't meet the demand of vocational students in major setting and curriculum management. The university should know more about the demands of the students and make some adjustment. Secondly, university should improve the living dormitory management system and the democratic management concept. It can largely enhance the satisfaction of male students if the university improves the dormitory facilities and sports and recreational facilities. Compared with women, men are lower in overall expectation, and men are easier to be satisfied. Thirdly, it exists difference in different grade; the university should pay more attention to the third grade.

\section{ACKNOWLEDGEMENTS}

This research is sponsored by Graduate Education Reform
project:Evaluation of Graduate Education Service Quality Based on Kano Model (JGZZ14_015) and China Association for International Education research project: Empirical Analysis on Higher Education Service Quality Based on Customer Satisfaction Model (2002Y009).

\section{REFERENCES}

[1] Aldridge, S., \& Rowley, J. (1998). Measuring customer satisfaction in higher education. Quality Assurance in Education, 6(4), 197-204.

[2] Athiyaman, A. (1997). Linking student satisfaction and service quality perceptions: the case of university education. European Journal of Marketing, 31(7), 528-540.

[3] Moogan, Y. J., Baron, S., \& Bainbridge, S. (2001). Timings and trade-offs in the marketing of higher education courses: a conjoint approach. Marketing Intelligence\& Planning, 19(3), 179-187.

[4] Oldfield, B., \& Baron, S. (2000). Student perceptions of service quality in a UK university business and management faculty. Quality Assurance in Education,8(2), 85-95.

[5] The American Heritage Dictionary. (1982). (2nd Ed.). Boston, MA: Houghton Mifflin Co.

[6] Kotler, P. \& Clarke, R.N. (1987).Marketing for health care organizations. Englewood Cliffs, NJ: Prentice-Hall.

[7] Schreiner, L. A., \&Juillerat, S. L. (1994).Student Satisfaction Inventory. Iowa City, IA: Noel-Levitz Centers, Inc.

[8] Sweeney, J.C., \& Ingram.D. (2001). A Comparison of Traditional and Web Marketing Education: An Exploratory Study. Journal of Marketing Education, 23(1), 55-62.

[9] Fang Baojun, Chen Min. Influencing Factors of the Engineering Undergraduate Teaching Quality Based on Students' Satisfaction. Journal of higher Education. 2010(6),78-83

[10] Yang Lanfang, Chen Wanming, Wu Qingxian. Study on the Status of Students' Satisfaction with the Quality of Higher Education Service and Its Influencing Factors: Based on a Survey Analysis of Undergraduates in Eight Colleges of Jiangsu. Value Engineering. 2011(34)

[11] Martilla, J. A., \& James, J. C. (1977). Importance-performance analysis. Journal of Marketing, 41(1), 77-79.

[12] De Jager, J.W., \& Gbadamosi, G. (2009). 'Specific remedy for specific problem: measuring service quality in South African higher education. Higher Education, 60(3), 251-267. 